\title{
Struktur Populasi Ikan Baronang pada Ekosistem Lamun Di Pesisir Pulau Bintan
}

\author{
Jemi, Ita Karlina, Aditya Hikmat Nugraha* \\ Program Studi IImu Kelautan, Fakultas IImu Kelautan dan Perikanan, Universitas Maritim Raja Ali Haji \\ Jl. Politeknik Senggarang, Tanjungpinang, Kepulauan Riau 29100 Indonesia \\ ${ }^{\star}$ Corresponding author : adityahn@umrah.ac.id
}

\begin{abstract}
ABSTRAK: Salah satu ekosistem pesisir yang dapat ditemukan di pesisir Pulau Bintan yaitu ekosistem lamun. Ikan baronang merupakan ikan ekonomis penting yang berasosiasi dengan padang lamun. Kondisi struktur ekosistem lamun yang berbeda di perairan pulau Bintan diduga dapat berpengaruh terhadap persebaran ikan baronang pada ekosistem lamun. Penelitian ini bertujuan untuk mendeskripsikan kondisi tutupan lamun pada beberapa lokasi dan mendeskripsikan struktur populasi ikan baronang (Siganus sp) pada ekosistem lamun dengan tutupan berbeda di perairan pulau Bintan. Metode sampling tutupan lamun menggunakan transek kuadrat berukuran $50 \times 50 \mathrm{~cm}$ dan sampling ikan baronang menggunakan jaring insang dasaran (bottom gill net). Diperoleh 8 jenis lamun yang tersebar di 4 stasiun penelitian. Tutupan lamun tertinggi terdapat di stasiun Pengudang dengan nilai 65,20\% dengan kondisi kaya/padat. Terdapat 5 jenis ikan baronang. Jenis ikan baronang yang memiliki kelimpahan tertinggi yaitu Siganus canaliculatus. Tidak terjadi perbedaan yang signifikan untuk persebaran jenis ikan baronang pada lokasi penelitian
\end{abstract}

Kata kunci : Asosiasi, Bintan, Ekosistem, Lamun, Siganus

\section{Population Structure of Siganus sp. in Seagrass Ecosystems at Bintan Island}

\begin{abstract}
One of the ecosystems that can be found on the coast of Bintan Island is the seagrass ecosystem. Slganus $s p$ are economical fish associated with seagrass beds. The structure of the seagrass ecosystem is thought to have an effect on the distribution of Siganus $s p$ in the seagrass ecosystem. This study aims to describe the condition of seagrass cover at several locations in the waters of Bintan Island and to describe the population structure of Siganus sp in seagrass ecosystems with different cover in the waters of Bintan Island. The seagrass cover sampling method used a quadratic transect measuring $50 \times 50 \mathrm{~cm}$ and the Siganus sp fish sampling used a bottom gill net. Obtained 8 types of seagrass spread over 4 research stations. The highest seagrass cover was found at Pengudang station with a value of $65.20 \%$ with rich/dense conditions. There are 5 types of baronang fish. The type of baronang fish that has the highest abundance is Siganus canaliculatus. There is no significant difference for the distribution of baronang fish species at the study site.
\end{abstract}

Keywords : Associated, Bintan, Ecosystem, Seagrass, Siganus

\section{PENDAHULUAN}

Ekosistem lamun merupakan ekosistem pada wilayah perairan dangkal yang tersusun atas lamun yang merupakan satu satunya tumbuhan berbunga dan mampu hidup di bawah permukaan air laut. Ekosistem lamun memiliki peran penting sebagai kawasan asuhan, mencari makan bagi berbagai jenis biota laut, dan sebagai penyerap karbon terbesar (Koch et al., 2012). Salah satu jenis biota laut yang berasosiasi dengan ekosistem lamun yaitu ikan baronang (Kawaroe et al., 2016).

Ikan baronang (Siganus sp) merupakan salah satu biota ekonomis penting, yang termasuk dalam family Siganidae dan hidup di dasar perairan (demersal). Ikan tersebut banyak ditemukan di padang lamun maupun di terumbu karang (Syafrudin, 2008). Ekosistem padang lamun dimanfaatkan ikan baronang sebagai tempat mencari makanan (feeding ground), tempat pemijahan (spawning ground), dan sebagai daerah asuhan (nursery ground) (Kordi, 2011). 
Pulau Bintan merupakan salah satu pulau di kawasan Kepulauan Riau. Hamparan padang lamun hampir dapat ditemukan di seluruh area pesisir Pulau Bintan dengan (Nugraha et al., 2021). Terdapat 10 spesies lamun di pulau Bintan, meliputi: Enhalus acoroides, Halophila ovalis, $H$. minor, $H$. spinulosa, Thalassia hemprichii, Cymodocea serrulata, C. rotundata, Halodule uninervis, H. pinifolia, dan Syringodium isoetifolium. (Kawaroe et al., 2016).

Kondisi struktur ekosistem lamun di perairan pulau Bintan umumnya memiliki tutupan yang berbeda di setiap lokasi (Nugraha et al., 2021). Hal tersebut dipengaruhi oleh adanya perbedaan kondisi lingkungan perairan dan aktivitas manusia di sekitarnya. Perbedaan struktur ekosistem lamun berpengaruh terhadap jasa ekosistem lamun, seperti halnya dalam proses penyerapan karbon (Nugraha et al.,2019). Menurut Aprilio et al. (2016), Kondisi kelimpahan dan keanekaragaman ikan baronang (Siganus sp) dipengaruhi oleh kondisi ekosistem padang lamun. Oleh karena itu sangat penting untuk mengetahui persebaran populasi ikan baronang pada kondisi struktur ekosistem lamun yang berbeda. Penelitian ini bertujuan untuk mendeskripsikan struktur ekosistem (tutupan lamun) dan populasi ikan baronang pada beberapa lokasi di perairan pulau Bintan

\section{MATERI DAN METODE}

Penelitian ini dilaksanakan pada bulan November hingga Desember 2020. Materi yang digunakan dalam penelitian ini meluputi lamun dan ikan baronang (Siganus sp). Terdapat empat stasiun pada penelitian ini (Gambar 1). Stasiun 1 berada di Desa Pengudang (Bintan Utara), stasiun 2 berada di Teluk Bakau (Bintan Timur), stasiun 3, berada di Dompak (Bintan Selatan) dan stasiun 4 berada di Desa Pengujan (Bintan Barat). (Gambar 1). Keempat stasiun yang diambil dianggap mewakili pesisir yang berada di perairan Pulau Bintan. Stasiun 1 termasuk ke dalam kawasan konservasi padang lamun. Stasiun 2 termasuk ke dalam kawasan yang berdekatan dengan pemukiman masyarakat terdapat aktivitas pariwisata dan ditemukan juga aktivitas penangkapan ikan. Stasiun 3 termasuk ke dalam kawasan yang sangat jauh dari pemukiman tetapi beberapa ditemukan aktivitas penangkapan ikan. Stasiun 4 termasuk ke dalam kawasan yang berdekatan dengan masyarakat dan aktivitas penangkapan yang cukup tinggi. Parameter yang diamati pada penelitian ini meliputi tutupan lamun, kelimpahan ikan baronang, karakteristik morfometrik ikan baronang seperti panjang dan bobot.

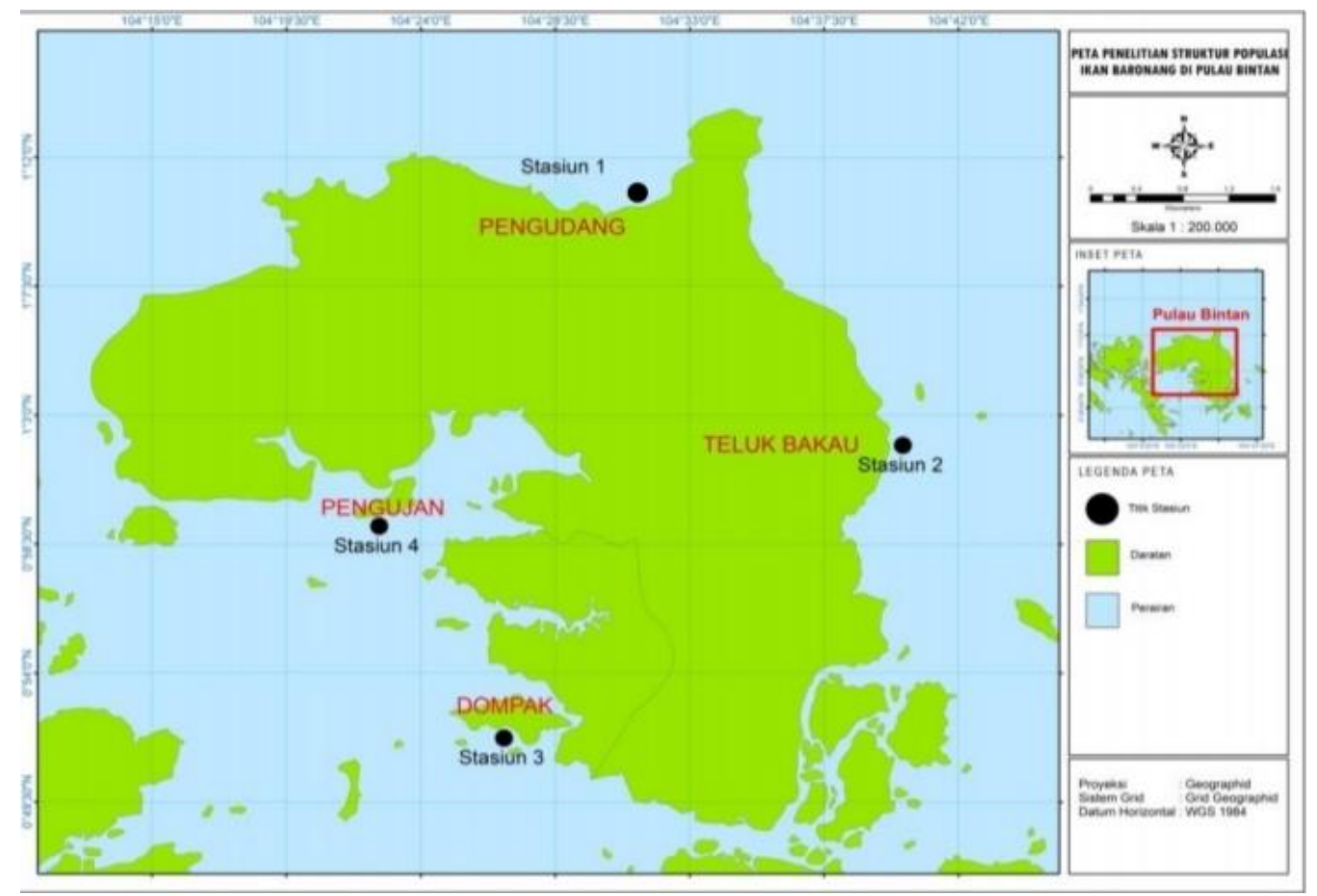

Gambar 1. Peta lokasi penelitian 
Pengambilan data tutupan lamun dilakukan menggunakan metode yang dikemukakan oleh (Rahmawati et al., 2014) yaitu dengan cara membentangkan tiga buah transek garis sepanjang $100 \mathrm{~m}$ kearah laut dimulai dari ditemukannya lamun. Transek diletakkan di setiap stasiun dengan jarak antar transek sepanjang $50 \mathrm{~m}$. Transek ditarik tegak lurus dengan garis pantai dan setiap transek sejajar dengan transek lainnya. Kondisi padang lamun dinilai dengan mengukur tutupan lamun dengan bantuan transek kuadrat $(50 \times 50 \mathrm{~cm})$ sepanjang transek garis. Transek kuadrat dimulai dari titik $0 \mathrm{~m}$ sampai $100 \mathrm{~m}$ dengan jarak antar kuadrat $10 \mathrm{~m}$.

Pengambilan data kelimpahan ikan baronang berdasarkan kepada jumlah ikan yang tertangkap di dalam jaring insang (gill net bottom) di setiap lokasi penelitian. Jaring insang yang digunakan memiliki karakteristik dengan ukuran mata jaring 11/2 inci, panjang 100 meter, dan lebar 2 meter. Jaring dipasang pada saat air pasang. Ikan. Pengambilan data ikan baronang dilakukan dengan membentangkan jaring insang sepanjang 100 meter melintang dari 3 lokasi transek lamun dimulai dari titik 50 meter transek pertama sampai ke titik 50 meter pada transek ke tiga. Sampel ikan yang didapat kemudian diidentifikasi dan dihitung jumlahnya. Selanjutnya dilakukan pengukuran panjang total dan bobot (Hartono et al., 2019). Hubungan panjang dan bobot dihitung dengan menggunakan persamaan yang dikemukakan oleh (Effendie, 1997). Pencarian hubungan panjang dan bobot dilakukan untuk mengetahui pola pertumbuhan ikan baronang.

Analisis korespondensi (CA) merupakan cara untuk mengelompokkan satuan statistik ke dalam kelompok homogen berdasarkan variabel. Analisis korespondensi mengklaster objek sesuai kriteria yang digunakan, sehinga objek serupa akan dikelompokkan dalam kelas yang sama. (Radiarta \& Erlania, 2015). Proses pengolahan data dilakukan dengan menggunakan xlstat. Analisis korespondensi digunakan untuk menganalisis keterkaitan persebaran ikan baronang pada ekosistem lamun terhadap lokasi penelitian.

\section{HASIL DAN PEMBAHASAN}

Persentase tutupan lamun menunjukkan seberapa luas lamun yang menutupi suatu dasar perairan. Jenis lamun yang berbeda memiliki ukuran yang berbeda sehingga berpengaruh terhadap penutupan substrat, semakin lebar daun maka semakin luas substat yang tertutupi (Fahruddin et al., 2017). Persentase tutupan lamun pada lokasi penelitian disajikan pada Gambar 2.

Berdasarkan informasi pada Gambar 2, persentase tutupan lamun di stasiun Pengudang sebesar $65,20 \%$, dengan kategori lamun padat. Berdasarkan penentuan status padang lamun menurut Keputusan Menteri Lingkungan Hidup No.200 tahun 2004, lamun di perairan Pengudang tergolong dalam kondisi tutupan kaya/sehat dengan nilai persentase penutupan yaitu $\geq 59,90 \%$. Stasiun Teluk Bakau memiliki tutupan lamun sebesar 42,05\%, Stasiun Dompak memiliki tutupan lamun sebesar $44,70 \%$ dan stasiun Pengujan sebesar $49,47 \%$. Stasiun yang memiliki persentase tutupan lamun $<59,90 \%$ dapat dikategorikan ekosistem lamun di stasiun tersebut kurang kaya/kurang sehat. Besar kecilnya nilai tutupan lamun dapat dipengaruhi oleh aktivitas masyarakat di sekitar ekosistem lamun (Unsworth et al., 2018). Dampak dari aktivitas masyarakat tersebut dapat menyebabkan terjadinya kekeruhan yang menghambat fotosinesis. Menurut Christon et al. (2012) kekurangan cahaya akan mempengaruhi fotosintesis dan pertumbuhan lamun. Rappe (2014) menyatakan bahwa aktivitas antropogenik cenderung menghasilkan efek terhadap ekosistem lamun yang berdekatan dengan kawasan daratan utama.

Terdapat 8 jenis lamun yang ditemukan di seluruh stasiun penelitian, yaitu meliputi jenis Enhalus acoroides, Thalassia hemprichii, Halophila ovalis, Halodule uninervis, Cymodocea rotundata, Cymodocea serrulata, Thalassodedron ciliatum, dan Syringodium isoetifolium. Lamun jenis E.acoroides dan T.hemprichii umumyna memiliki tutupan tinggi di seluruh lokasi penelitian. Lamun jenis $E$. acoroides dan $T$. hemprichii memiliki ukuran daun yang lebih besar sehingga substrat yang tertutupi daun akan semakin luas dibandingkan dengan lamun jenis lainnya. Jenis substrat di lokasi penelitian yaitu pasir berlumpur dan pasir berkerikil. Menurut Tangke (2010), lamun dengan diameter besar hidup pada substrat dasar berpasir, pasir berlumpur, dan kadangkadang terdapat pada dasar pecahan karang yang sudah mati. Lamun jenis T.hemprichii dapat hidup dengan baik pada substrat berpasir dengan diameter besar (Yunitha et al.,2014). Selain itu lamun jenis E.acoroides dan $T$ hemprichii merupakan lamun yang memiliki tingkat adaptasi tinggi terhadap variasi kondisi lingkungan perairan, sehingga dapat mendominansi di suatu perairan (Kilminster et al.,2015) 


\section{Kelimpahan Ikan Baronang (Siganus sp)}

Jumlah ikan baronang yang terkumpul selama penelitian di seluruh lokasi sebanyak 130 ekor yang terdiri dari lima jenis ikan baronang. Kelimpahan ikan baronang pada setiap stasiun penelitian disajikan pada Gambar 3.

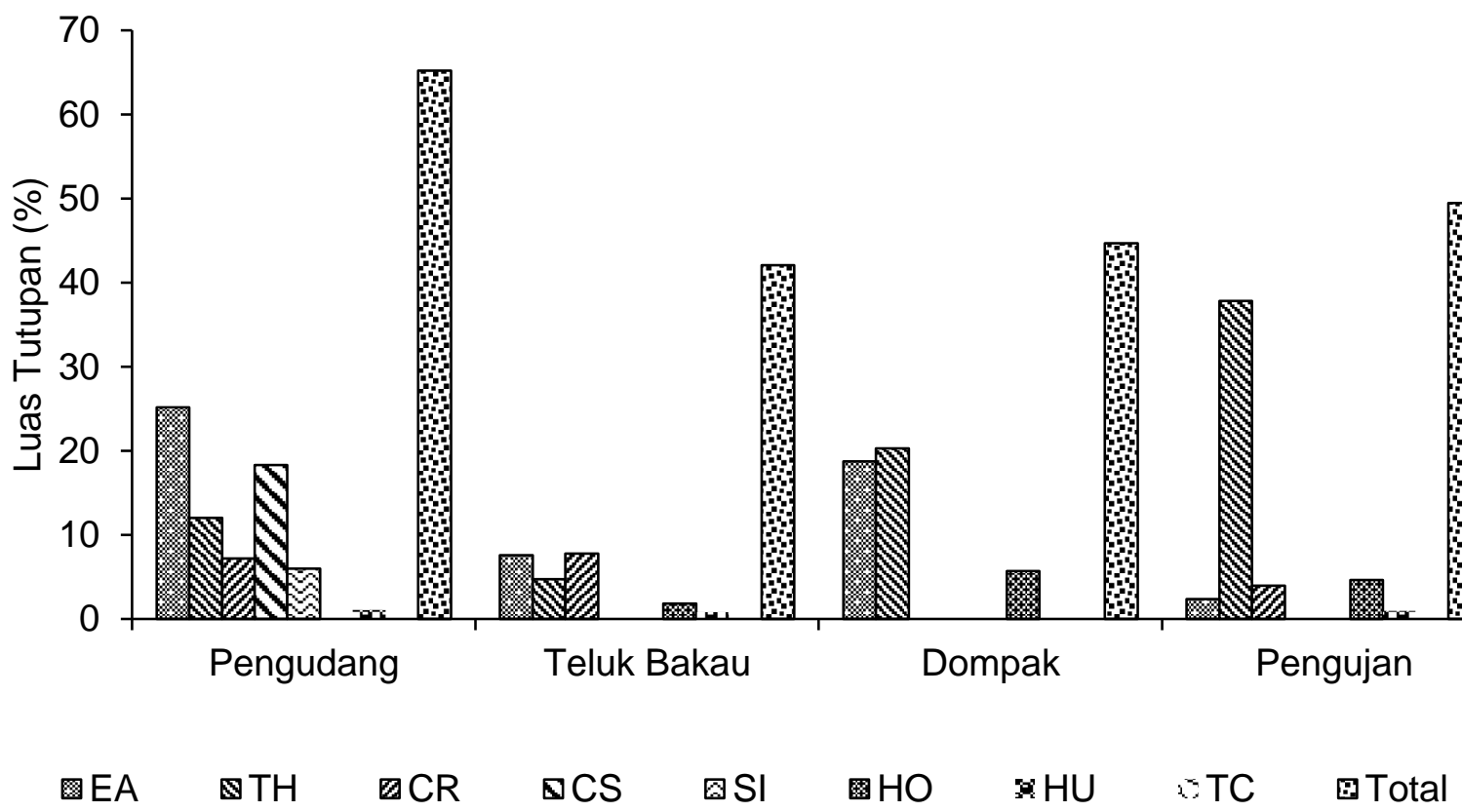

Gambar 2. Persentase tutupan lamun $(E A=$ Enhalus acoroides, $T H=$ Thalassia hemprichii, $H O=$ Halophila ovalis, $H U=$ Halodule uninervis, $C R=$ Cymodocea rotundata, $C S=$ Cymodocea serrulata, $T C=$ Thalassodendron ciliatum, $S I=$ Syringodium isoetifolium)

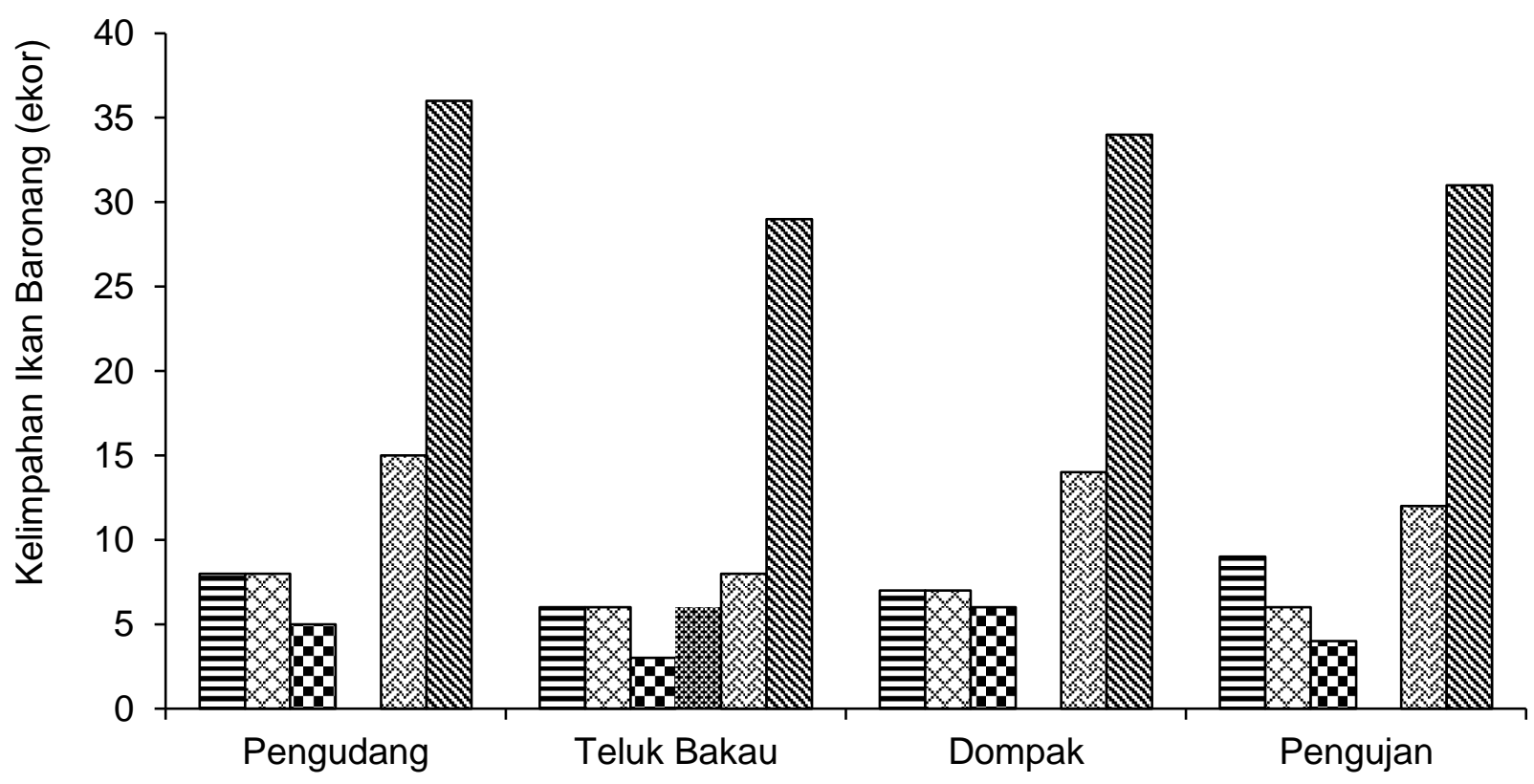

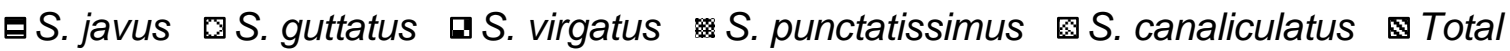

Gambar 3. Kelimpahan Ikan Baronang (Siganus sp) 
Kelimpahan ikan baronang tertinggi terdapat di stasiun Pengudang dengan kelimpahan 36 individu. Tidak ditemukan perbedaan kelimpahan ikan baronang yang begitu jauh berbeda antara lokasi penelitian. Jenis Siganus canaliculatus merupakan jenis yang mendominasi di seluruh stasiun penelitian. Hasil yang sama ditemukan oleh Rappe (2010) yang melakukan penelitian di Pulau Barrang Lompo menyatakan bahwa ikan yang banyak ditemukan di padang lamun adalah jenis Siganus canaliculatus. Hasil tersebut juga sejalan dengan penelitian yang dilakukan di perairan Tanjung Tiram-Teluk Ambon Dalam bahwa spesies ikan dengan kelimpahan tertinggi di padang lamun adalah Siganus canaliculatus (Latuconsina et al., 2013). Tingginya kelimpahan Siganus canaliculatus diduga karena kebiasaan hidup bergerombol di padang lamun (Genisa, 1999). Siganus canaliculatus merupakan jenis ikan baronang yang berasosiasi dengan ekosistem lamun (Kawaroe et al., 2016).

Kelimpahan ikan baronang terendah terdapat di stasiun Teluk Bakau dengan kelimpahan 29 individu. Pada stasiun Teluk Bakau ditemukan jenis ikan baronang yang tidak ditemukan pada tiga stasiun lainnya yaitu jenis Siganus puncatissimus. Hal tersebut diduga karena Siganus puncatissimus merupakan jenis ikan baronang yang berasosiasi dengan terumbu karang sehingga kemunculannya sangat sedikit di ekosistem lamun. Menurut Indrawati et al. (2020), salah satu jenis ikan dari family Siganidae yang merupakan ikan target di terumbu karang adalah Siganus puncatissimus. Berdasarkan pengamatan di lapangan, kondisi padang lamun yang berada di Desa Teluk Bakau tidak memiliki jarak yang cukup jauh dengan ekosistem terumbu karang.

\section{Karakteristik Panjang dan Bobot Ikan Baronang}

Karakteristik panjang bobot ikan baronang yang didapat pada penelitian ini selanjutnya disajikan pada Tabel 1. Berdasarkan hasil yang diperoleh dari pengukuran panjang dan bobot ikan baronang pada Tabel 2, terlihat bahwa kisaran panjang dan bobot untuk setiap jenis ikan baronang yang ditemukan pada setiap stasiun, memiliki kisaran nilai yang tidak jauh berbeda. Variasi ukuran pada ikan dapat dipengaruhi oleh beberapa faktor seperti tingkat kematangan gonad, jenis kelamin

Tabel 1. Karakteristik panjang bobot ikan baronang

\begin{tabular}{clccccc}
\hline \multirow{2}{*}{ Lokasi } & \multicolumn{1}{c}{ Spesies } & $\mathrm{n}$ & $\begin{array}{c}\text { Kisaran } \\
\text { Panjang } \\
\mathrm{cm}\end{array}$ & $\begin{array}{c}\text { Rata-Rata } \\
\text { Panjang } \\
\mathrm{cm}\end{array}$ & $\begin{array}{c}\text { Kisaran Bobot } \\
\text { gram }\end{array}$ & $\begin{array}{c}\text { Rata-Rata } \\
\text { Bobot } \\
\text { Gram }\end{array}$ \\
\hline \multirow{5}{*}{ Pengudang } & S. javus & 8 & $10,80-16,10$ & 13,28 & $29,80-57,12$ & 38,01 \\
& S. guttatus & 8 & $13,40-27,60$ & 18,58 & $42,12-137,40$ & 83,66 \\
& S. virgatus & 5 & $10,30-13,60$ & 12,34 & $22,61-37,46$ & 29,02 \\
& S. canaliculatus & 15 & $11,00-17,90$ & 13,51 & $24,37-59,73$ & 36,28 \\
\hline \multirow{5}{*}{ Teluk Bakau } & S. javus & 6 & $10,70-15,40$ & 13,43 & $28,82-55,41$ & 44,55 \\
& S. guttatus & 6 & $15,30-21,30$ & 17,60 & $61,88-101,72$ & 88,27 \\
& S. virgatus & 3 & $9,80-12,10$ & 10,73 & $19,74-35,36$ & 25,25 \\
& S. punctatissimus & 6 & $12,20-18,00$ & 14,27 & $25,76-94,32$ & 49,62 \\
& S. canaliculatus & 8 & $11,80-17,80$ & 14,28 & $26,18-61,17$ & 40,44 \\
\hline \multirow{5}{*}{ Dompak } & S. javus & 7 & $8,80-16,10$ & 13,40 & $30,07-51,76$ & 40,92 \\
& S. guttatus & 7 & $17,40-22,20$ & 20,09 & $88,52-127,38$ & 103,63 \\
& S. virgatus & 6 & $9,90-12,60$ & 10,95 & $19,88-35,47$ & 26,26 \\
& S. canaliculatus & 14 & $12,00-17,90$ & 13,81 & $25,67-59,73$ & 35,64 \\
\hline \multirow{5}{*}{ Pengujan } & S. javus & 9 & $11,40-15,70$ & 13,58 & $30,09-47,60$ & 39,55 \\
& S. guttatus & 6 & $12,70-21,60$ & 17,87 & $36,48-137,30$ & 86,63 \\
& S. virgatus & 4 & $8,60-12,60$ & 11,23 & $19,97-33,80$ & 26,10 \\
& S. canaliculatus & 12 & $12,00-15,90$ & 13,20 & $25,67-47,87$ & 32,61 \\
\hline
\end{tabular}


serta musim pemijahan (Mayunar, 1992). Selain itu faktor lain seperti ketersediaan makanan, habitat dan kondisi lingkungan menjadi faktor adanya variasi pada ukuran ikan (Asriyana, 2015). Kondisi struktur ekosistem lamun yang tidak jauh berbeda antara stasiun pengamatan diduga berdampak kepada tidak terjadinya variasi ukuran pada ikan baronang yang ditemukan. Sebagaimana diketahui bahwasanya seluruh stasiun pengamatan memiliki struktur ekosistem lamun yang tediri dari vegetasi campuran. Struktur ekosistem lamun dengan struktur vegetasi campuran merupakan tempat juvenil dan pembesaran bagi ikan baronang (Latuconsina et al., 2020).

Berdasarkan panjang dan bobot ikan baronang, ikan baronang dapat dikelompokan menjadi: ikan juvenil berkisar antara 32,50-62,50 mm, pra dewasa berkisar antara 77,60-122,50 $\mathrm{mm}$, dan ikan dewasa kisarannya $>137,50 \mathrm{~mm}$ (Kwak et al., 2015). Menurut Latuconsina et al., (2020), kriteria panjang bobot Siganus canaliculatus yaitu: juvenil 2,50-6,50 cm, pra dewasa 6,6012,50 , dan dewasa $\geq 12,60$

Berdasarkan data yang disajikan pada Gambar 5 , hasil pengukuran panjang dan bobot ikan baronang pada seluruh stasiun penelitian didominasi oleh ikan barpnang kategori dewasa. Berdasarkan hasil yang diperoleh pada penelitian ini, di bulan November hingga Desember secara keseluruhan ikan baronang didominasi oleh ikan baronang pra dewasa $(27,69 \%)$ dan dewasa $(72,31 \%)$. Hal ini diduga pada bulan November hingga Desembar ikan baronang dalam fase matang gonad. Penelitian yang dilakukan di Pesisir Uloulo Kabupaten Luwu didapati hasil kelimpahan ikan baronang tertinggi pada bulan Desember karena pengaruh makanan dan pemijahan (Suardi et al., 2019). Ketersediaan makanan mempercepat pertumbuhan dan memijah (Natsir, 2007).

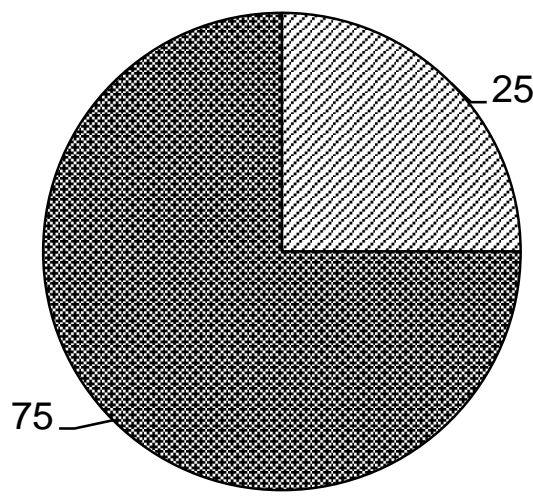

๑Pra dewasa Dewasa

Pengudang

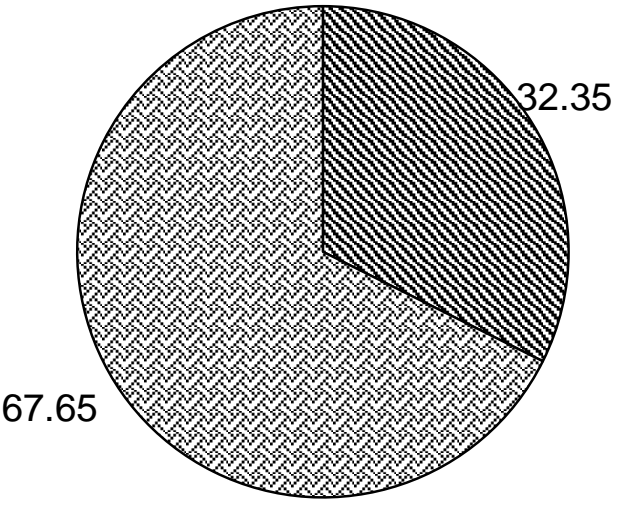

\$ Pra dewasa Dewasa

Dompak

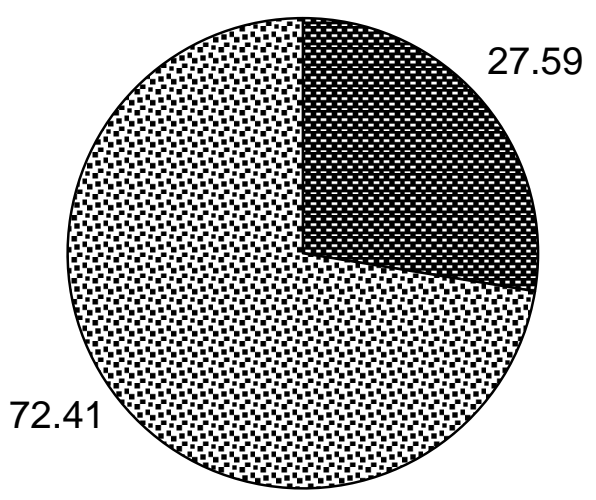

Pra dewasa Dewasa

Teluk Bakau

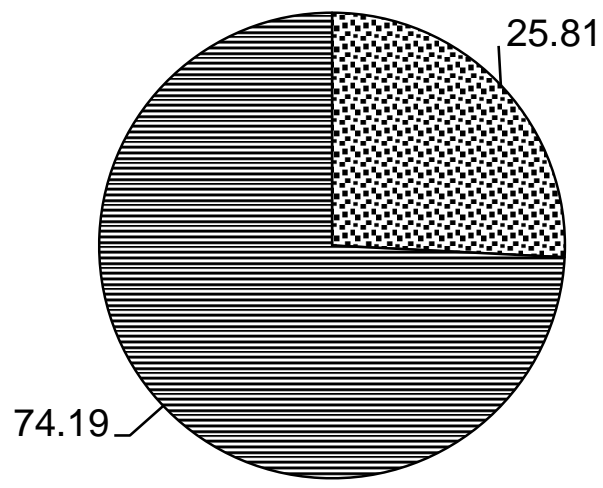

⿴囗十 Pra dewasa 目Dewasa

Pengujan

Gambar 5. Kriteria panjang bobot ikan baronang tiap lokasi 


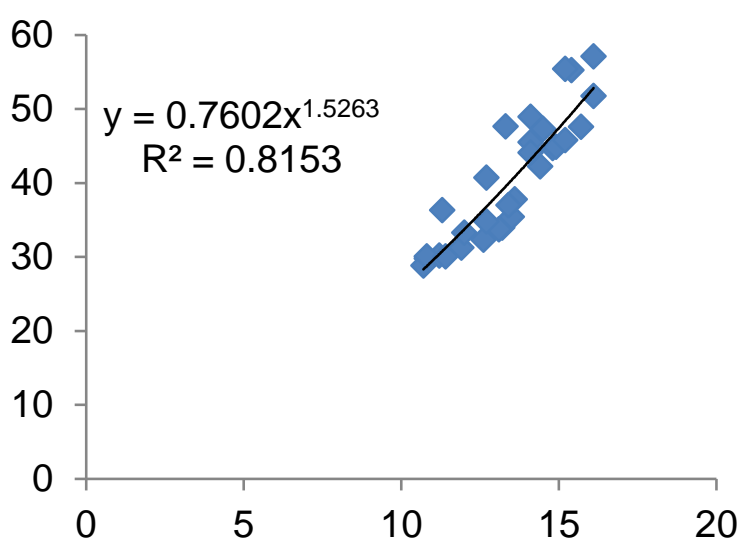

Siganus javus

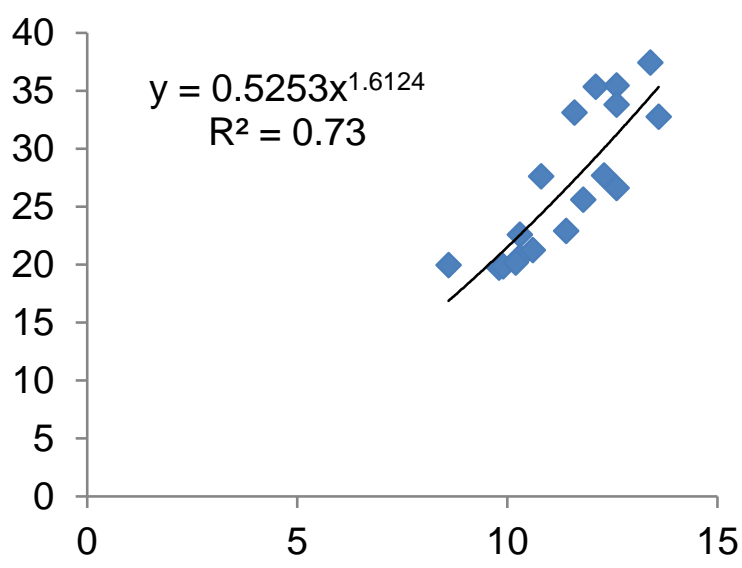

Siganus virgatus

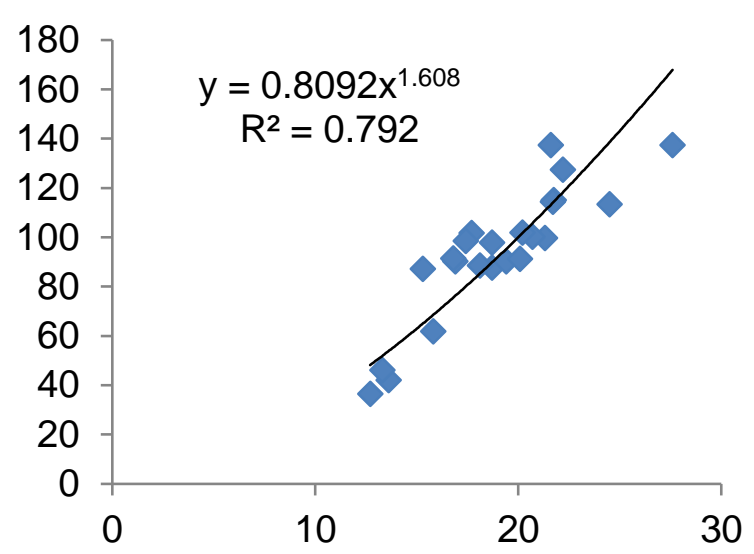

Siganus guttatus

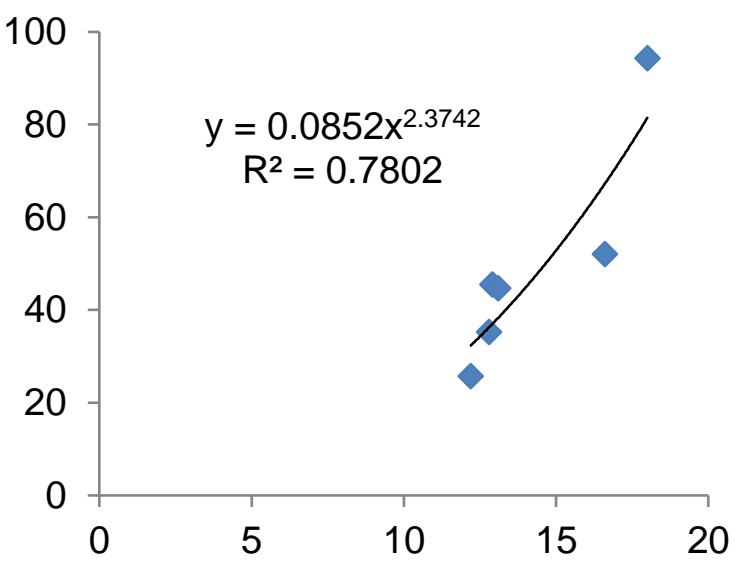

Siganus punctatissimus

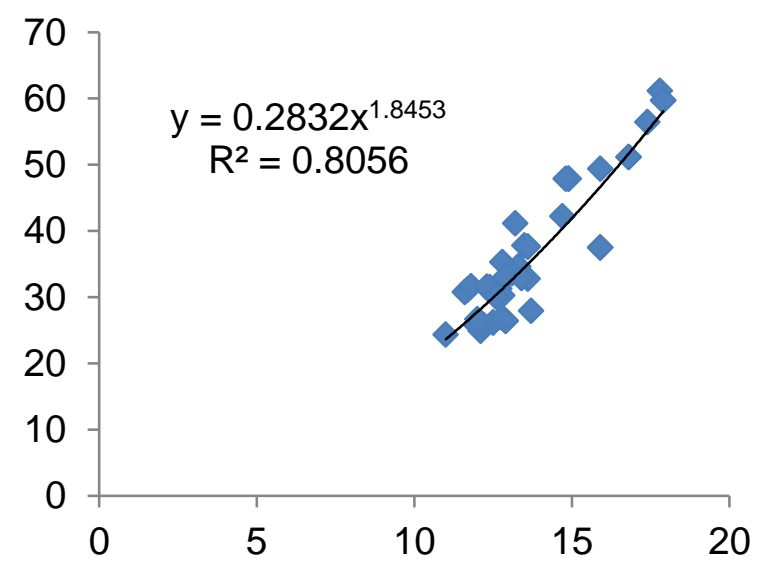

Siganus canaliculatus

Gambar 6. Hubungan panjang bobot ikan baronang

Berdasarkan hasil perhitungan hubungan panjang berat ikan baronang terdapat nilai $b$ yang berbeda beda, Siganus javus memiliki nilai $(b=1,5263)$, Siganus guttatus memiliki nilai $(b=1,608)$, Siganus virgatus memiliki nilai $(b=1,6124)$, Siganus punctatissimus memiliki nilai $(b=2,3742)$, dan Siganus canaliculatus memiliki nilai $(b=1,8453)$. Berdasarkan 5 jenis ikan baronang yang diperoleh, memiliki nilai $b$ kurang dari 3 yang artinya pertumbuhan ikan baronang allometrik negatif $(\mathrm{b}<3)$, dimana pertumbuhan panjang lebih cepat daripada pertumbuhan beratnya. Hasil penelitian Setiawan et al., (2019) yang dilakukan di perairan Maluku mendapati nilai b dari jenis Siganus canaliculatus yaitu $\mathrm{b}=2,196$ yang artinya pertumbuhan Siganus canaliculatus adalah allometrik negatif. 
Ikan baronang memiliki pertumbuhan allometrik negatif $(b<3)$ pada bulan April dan Mei di Perairan Tondonggeu Kecamatan Abeli Kota Kendari (Sudarno et al., 2018). Siganus guttatus memiliki pertumbuhan isometrik pada bulan Oktober di perairan Sei Carang, Kota Tanjungpinang yaitu pertumbuhan total panjang tubuh dan pertumbuhan bobotnya seimbang (Indriyani et al., 2020). Hal ini dimungkinkan karena pengaruh faktor biologis dan ekologis seperti temperatur, ketersediaan makanan, tempat tinggal, dan waktu penangkapan. Perbedaan nilai $b$ dipengaruhi oleh kondisi kebugaran suatu spesies, ketersedaiaan makanan dan kecepatan dalam memangsa target (Kusmini et al., 2016).

\section{Sebaran Populasi Ikan Baronang pada Ekosistem Lamun di Lokasi Penelitian}

Sebaran populasi ikan baronang yang terdiri dari jenis baronang Siganus javus, Siganus guttatus, Siganus virgatus, Siganus punctatissimus, dan Siganus canaliculatus pada stasiun penelitian dianalisis dengan menggunakan correspondence analysis (CA). Hasil Correspondence Analysis dapat dilihat pada Gambar 7.

Hasil Correspondence Analysis memiliki kontribusi pada sumbu F1 sebesar $53,30 \%$ dan sumbu F2 sebesar 34,69\%. Stasiun Pengudang dicirikan oleh Enhalus acoroides, Cymodocea serrulata, Syringodium isoetifolium, dan Thalassodendron ciliatum. Stasiun Teluk Bakau dicirikan oleh Siganus guttatus, Siganus punctatissimus, Cymodocea rotundata, dan Halodule uninervis. Stasiun Dompak dicirikan oleh Siganus virgatus dan Siganus punctatissimus. Sedangkan di stasiun Pengujan dicirikan oleh Siganus javus, Thalassia hemprichii, dan Halophila ovalis.

Berdasarkan hasil analisis koresponden, tidak terjadi perbedaan jenis ikan baronang yang signifikan pada semua stasiun dikarenakan jenis lamun yang disukai ikan baronang terdapat di seluruh stasiun penelitian. Hal ini juga didudukung dengan nilai tutupan lamun yang tidak jauh berbeda antara lokasi penelitian. Lam (1974), mengatakan bahwa habitat Siganus canaliculatus berasosiasi kuat dengan vegetasi lamun jenis Enhalus acoroides. Hutomo (1985), menemukan komposisi makanan dari Siganus sp sbesar 46,67\% yang didominasi oleh lamun jenis Enhalus acoroides, Cymodocea serrulata, Syringodium isotifolium, dan Thalassia hemprichii. Terdapat fragmen lamun sebesar $95,06 \%$ dalam isi lambung Siganus canaliculatus yang didominasi lamun jenis Enhalus acoroides (Latuconsina et al., 2013). Enhalus acoroides memiliki ruang penempelan epifit yang luas sebagai sumber makanan bagi ikan baronang (Latuconsina et al., 2020).

Symmetric plot

(axes F1 and F2: $87.99 \%$ )

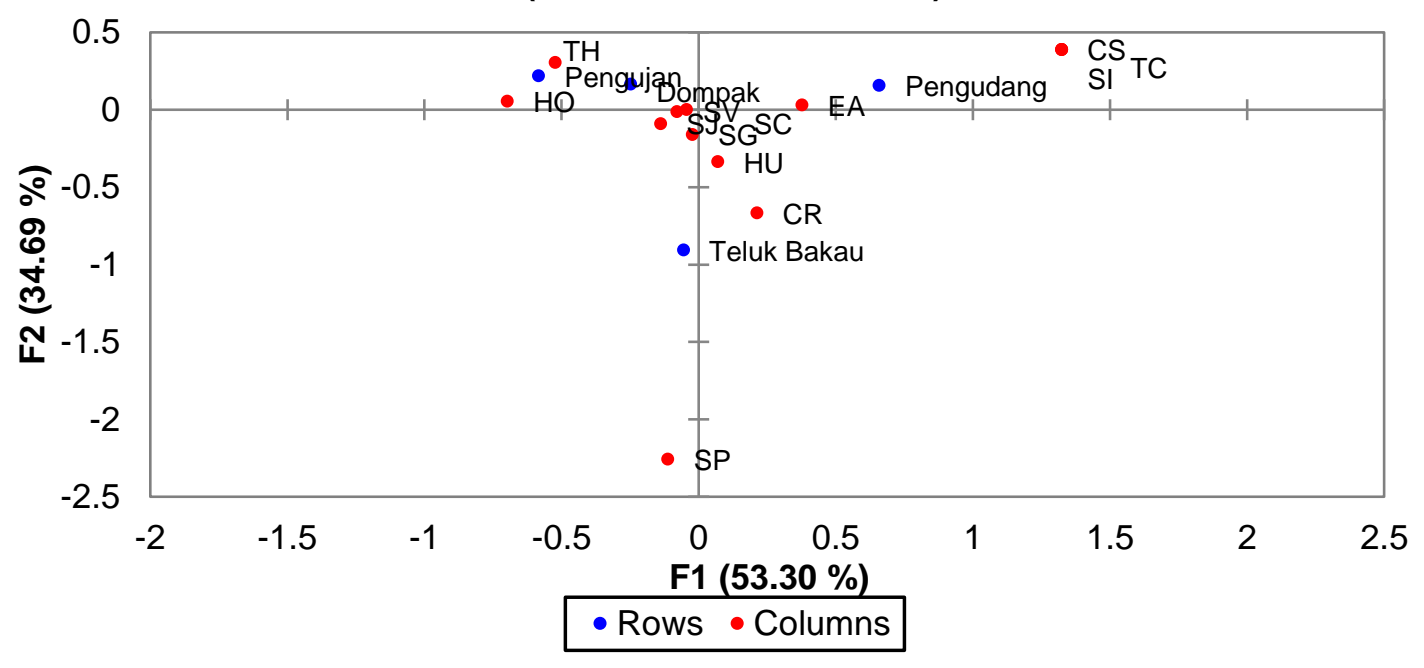

Gambar 7. Grafik Correspondence Analysis (CA). (EA=Enhalus acoroides, TH=Thalassia

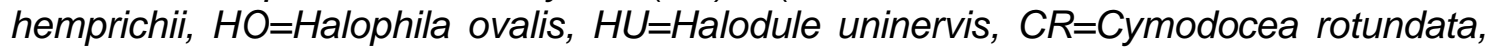
$C S=C y m o d o c e a$ serrulata, $T C=$ Thalassodendron ciliatum, $S I=S y r i n g o d i u m$ isoetifolium, $S J=$ Siganus javus, $S G=$ Siganus guttatus, SV=Siganus virgatus, $S C=$ Siganus canaliculatus, $S P=$ Siganus punctatissimus). 


\section{KESIMPULAN}

Terdapat 8 jenis lamun yang ditemukan diseluruh lokasi penelitian, yaitu Enhalus acoroides, Thalassia hemprichii, Halophila ovalis, Halodule uninervis, Cymodocea rotundata, Cymodocea serrulata, Thalassodedron ciliatum, dan Syringodium isoetifolium. Struktur ekosistem lamun di seluruh stasiun pengamatan berupa vegetasi campuran. Persentase tutupan lamun tertinggi diperoleh di stasiun Pengudang dengan kondisi kaya/padat. Kelimpahan ikan baronang tertinggi diperoleh di stasiun Pengudang. Terdapat empat jenis Ikan baronang yang diperoleh dari keempat stasiun penelitian yaitu: Siganus javus, Siganus guttatus, Siganus virgatus, Siganus punctatissimus dan Siganus canaliculatus. Jenis Siganus canaliculatus merupakan jenis yang paling mendominasi. Berdasarkan hasil analisis korespondensi umumnya tidak terdapat perbedaan yang signifikan pada persebaran jenis ikan baronang pada ekosistem lamun di perairan Pulau Bintan.

\section{DAFTAR PUSTAKA}

Aprilio, S.F., Riyantini, I., Pribadi, D.J., \& Hamdani, H. 2016. Korelasi kelimpahan ikan baronang (Siganus sp) dengan ekosistem padang lamun di perairan pulau Pramuka Taman Nasional Kepulauan Seribu. Perikanan Kelautan, 7(1): 165-171.

Asriyana, A. 2015. Pertumbuhan dan faktor kondisi ikan siro, Sardinella atricauda,Gunther 1868 (Pisces: Clupeidae) di Perairan Teluk Kendari, Sulawesi Tenggara. Jurnal Ikhtiologi Indonesia, 15(1): 77-86. DOI : 10.32491/jii.v15i1.77

Christon, C., Djunaedi, O.S., \& Purba, N.P. 2012. Pengaruh tinggi pasang surut terhadap pertumbuhan dan biomassa daun lamun Enhalus acoroides di pulau Pari Kepulauan Seribu, Jurnal Perikanan dan Kelautan, 3(3): 287-294.

Effendie, M.I. 1997. Biologi Perikanan. Cetakan pertama. Yayasan Pustaka Nusantara, Yogyakarta. 163 Halaman.

Fahruddin, M., Yulianda. F., \& Setyobudiandi, I. 2017. Kerapatan dan penutupan ekosistem lamun di pesisir Desa Bahoi, Sulawesi Utara. Jurnal IImu dan Teknologi Kelautan Tropis, 9(1): 375-383

Genisa, A.S. 1999. Pengenalan jenis-jenis ikan laut ekonomi penting di Indonesia. Oseana, 24(1): 17-38.

Hartono, A., Puspito, G., \& Mawardi, W. 2019. Uji coba lampu celup led pada jaring insang sebagai upaya meningkatkan hasil tangkapan. Jurnal Teknologi Perikanan dan Kelautan, 10(1): 15-26.

Hutomo M. 1985. Telaah Ekologi Komunitas Ikan Padang Lamun (Seagrass, Antophyta) di Perairan Teluk Banten. Disertasi. Fakultas Pascasarjana IPB. Bogor. 299 p.

Indrawati, A., Edrus, I.N., \& Hadi, T.A. 2020. Karakteristik struktur komunitas ikan karang target dan indikator di perairan taman nasional komodo. Jurnal Penelitian Perikanan Indonesia, 26(2): 75-92.

Indriyani, Y., Susiana, S., \& Apriadi,T. 2020. Kebiasaan makan ikan baronang (Siganus guttatus, Bloch 1787) di perairan Sei Carang Kota Tanjungpinang. Bawal, 12(2):51-60. DOI : 10.15578/ bawal.12.1.2020.51-60

Kawaroe, M., Nugraha, A.H., \& Juraij. 2016. Ekosistem padang lamun. Bogor. IPB Press. DOI : 10.13057/biodiv/d170228

Keputusan Menteri Negara Lingkungan Hidup No. 200 Tahun 2004. Tentang Kriteria Baku Kerusakan dan Pedoman Penentuan Status Padang Lamun.

Kilminster, K., McMahon, K., Waycott, M., Kendrick, G.A., Scanes, P., McKenzie, L., O'Brien K.R., Lyons, M., Ferguson, A., Maxwell, P., Glasby, T., \& Udy, J. 2015. Unravelling complexity in seagrass systems for management: Australia as a microcosm. Science Total Environment, 534: 97-109. DOI: 10.1016/j.scitotenv.2015.04.061.

Koch, E.W, Booth, D.M., \& Palinkas, C. 2012. Seagrasses and the ecosystem service of shoreline protection (or is it sediment stabilization?). In: Creed, J.C., OigmanPszczol, S.S. (Eds.), Proc. 10 ${ }^{\text {th }}$ Int. Seagrass Biology Workshop (ISBW10), 25-30 Nov. 2012. Armac, ão dos Búzios, Brazil. Instituto Biodiversidade Marinha, Rio deJaneiro, Brazil, 108 Halaman. 
Kordi, M.G. 2011. Ekosistem Lamun (Seagrass): Fungsi, Potensi, Pengelolaan. Rhineka Cipta, Jakarta. 191 Halaman.

Kusmini, I.I., Putri, F.P., \& Prakoso, F.A. 2016. Bioreproduksi dan hubungan panjang-bobot terhadap fekunditas pada ikan lalawak (Barbonymus balleraides). Jurnal Riset Akuakultur, 11(4): 339-345.

Kwak, S.N., Klumpp, D.W. \& Park, J.M. 2015. Feeding relationships among juveniles of abundant fish species inhabiting tropical seagrass beds in Cockle Bay, North Queensland, Australia. New Zealand Journal of Marine and Freshwater Research, 49(2): 205-223. DOI: 10.1080/00288330.2014.990467

Lam, T.J. 1974. Siganids: their biology and mariculture potential. Aquaculture, 3(4): 325-354. DOI: 10.1016/00448486(74)90001-5

Latuconsina, H. \& Rappe, R.A. 2013. Variabilitas harian komunitas ikan padang lamun perairan Tanjung Tiram-Teluk Ambon Dalam. Iktiologi Indonesia, 13(1):35-53.

Latuconsina, H., Affandi, R., Kamal, M.M., Butet, N.A. 2020. Distribusi spasial ikan baronang siganus canaliculatus park, 1797 pada habitat padang lamun berbeda di teluk Ambon Dalam. Jurnal IImu dan Teknologi Kelautan Tropis, 12(1): 89-106. DOI: 10.29244/jitkt.v12i1.27908

Mayunar. 1992. Pijah Rangsang Dan Pemeliharaan Larva Kerapu Lumpur, Epinephelus tauvina, Oseana 13(2): 69-82.

Natsir, M.M. 2007. Pengaruh penggunaan beberapa jenis enkapsulan pada asam laktat terenkapsulasi sebagai acidifier terhadap daya cerna protein dan factor metabolis ayam pedaging. Jurnal Ternak Tropika, 6(2): 13-17.

Nugraha, A.H., Kawaroe, M., Srimariana, E.S., Jaya, I., Apdillah, D., \& Deswati, S.R. 2019. Carbon storage in seagrass meadow of Teluk Bakau-Bintan Island. IOP Conference Series: Earth and Environmental Science, 278: 1-6.

Nugraha, A.H., Ramadani, P., Karlina, I., Susiana, S., \& Febrianto, T. 2021. Sebaran jenis dan tutupan lamun di perairan pulau Bintan. Jurnal Enggano, 6(2):323-332. DOI: 10.31186/ jenggano.6.2.323-332

Radiarta, I.N., \& Erlania. 2015. Analisis spasial dan temporal kondisi kualitas perairan melalui pendekatan statistik multivariat di Teluk Gerupuk, provinsi Nusa Tenggara Barat. Jurnal Riset Akuakultur, 10(3): 435-447.

Rahmawati, S., Irawan, A., Supriyadi, H.I., Azkab, M.H. 2014. Panduan Monitoring Padang Lamun LIPI. Jakarta. 45 Halaman.

Rappe, A.R. 2010. Struktur komunitas ikan pada padang lamun yang berbeda di pulau Barrang Lompo. Jurnal IImu dan Teknologi Kelautan Tropis, 2(2): 62-73.

Rappe, A.R. 2014. Developing a methodology of bioindication of human-induced effects using seagrass morphological variation in Spermonde Archipelago, South Sulawesi, Indonesia. Marine Pollution Bulletin, 86(1-2): 298-303. DOI: 10.1016/j.marpolbul.2014.07.002

Setiawan, R., Triyono, H., \& Jabbar, M.A. 2019. Aspek biologi Siganidae di perairan Maluku. Jurnal Penyuluhan Perikanan dan Kelautan,13(3): 287-300. DOI: 10.33378/jppik.v13i3.129

Suardi, Wiryawan, B., Taurusman, A.A., Santoso, J., \& Riyanto, M. 2019. Dinamika hasil tangkapan baronang (Siganus sp.) pada rumpon hidup secara spasial-temporal di pesisir Uloulo Kabupaten Luw. Marine Fisheries: Journal of Marine Fisheries Technology and Management,10(1): 45-57.

Sudarno, Asriyana. \& Arami, H. 2018. Hubungan panjang-bobot dan faktor kondisi ikan baronang (Siganus sp) di perairan Tondonggeu Kecamatan Abeli Kota Kendari. Sains dan Inovasi Perikanan, 2(1):30-39. DOI: 10.33772/jsipi.v2i1.7579

Syafrudin. 2008. Zona potensial penangkapan ikan baronang lingkis (Siganus canaliculatus) berdasarkan parameter oseanografi di perairan Tanakeke Kabupaten Takalar. Torani, 18(4): 325-335.

Tangke, T. 2010. Ekosistem padang lamun. Jurnal IImiah agribisnis dan Perikanan, 3(1): 9-29.

Unsworth, R. K., Ambo-Rappe, R., Jones, B. L., La Nafie, Y. A., Irawan, A., Hernawan, U. E., Moore, A.M., \& Cullen-Unsworth, L.C. 2018. Indonesia's globally significant seagrass meadows are under widespread threat. Science Total Environment, 634: 279-286. DOI: 10.1016/j.scitotenv.2018.03.315.

Yunitha, A., Wardiatno, Y., \& Yulianda, F. 2014. Diameter substrat dan jenis lamun di pesisir Bahoi Minahasa Utara: sebuah analisis korelasi. Jurnal Ilmu Pertanian Indonesia,19(3): 130-135. 